\title{
THE INFLUENCE OF HEALTH EDUCATION BY SNAKES AND LADDERS GAME TOWARD KNOWLEDGE LEVEL ABOUT COMPLICATIONS PREVENTION AMONG HIGH RISK PREGNANT WOMEN AT FIRST TRIMESTER
}

\author{
Meisya Alfia Rosada1), Tuti Sukini'2), Ribkha Itha Idhayanti3) \\ meisyarosada20@gmail.com \\ Health Polytechnic of Semarang \\ Midwifery Bachelor Study Program of Magelang
}

\begin{abstract}
Background: During the first trimester of pregnancy prenatal care, detection and prevention of complications need to be done so that it can be addressed immediately. In preventing pregnancy complications, midwives are expected to act as facilitators and can build persuasive communication. One strategy of midwives in building persuasive communication is by providing health education.

Purpose: The purpose of this study was to determine the effect of health education by snakes and ladders game toward knowledge level about complications prevention among high risk pregnant women at first trimester.

Methods: This research was conducted in the working area of Kedu Community Health Center-Temanggung Regency. The study was Pre Experimental design with One Group Pretest Posttest. The population was pregnant women at high risk of first trimester. Saturated sampling was done, leading to 34 respondents. Wilcoxon test was applied with $\mathrm{p}<0.05$.

Results : The test resulted in $\mathrm{p}$ value of $0.000(<0.05)$. It meant that health education by using snakes and ladders game influenced the knowledge level about complications prevention among high risk pregnant women at first trimester.

Conclusion: It can be infered that knowledge level about complications prevention was influenced by health education by using snakes and ladders game. Snakes and ladders game can be chosen as a way of health education that can increase the activity of participants.
\end{abstract}

Keywords: Health education; Snake and ladder game, high risk pregnant women

1) Student at the Midwifery Bachelor Study Program Magelang of Health Polytechnic Of Semarang

2,3) Lecturer at the Midwifery Bachelor Study Program Of Magelang of Health Polytechnic Of Semarang

Background. In the first trimester of pregnancy, screening, detection and prevention of complications need to be done to be resolved immediately. The complications that occur in the first trimester give a bad impact on the health of mothers and fetuses if not treated immediately (Manuaba, 2009). Complication of pregnancy in the first trimester such as anemia, hyperemesis gravidarum and young pregnancy bleeding when not immediately treated will lead to shock, bleeding, congenital defects even miscarriage (Marmi, Suryaningsih and Fatmawati, 2016).

Bleeding and conditions suffered by mothers such as cancer, kidney, heart, tuberculosis, and others to be the biggest cause of maternal death in year 2012-2013 namely bleeding (30.1 to 30.3 ) and the disease condition (34.5 to 40.8). (Kemenkes RI, 2014). The condition also affects the death of the mother in the Health Center in Kedu 
year 2017 - September 2018 as many as 2 people with the condition of disease is cancer and kidney. While the estimated number of the mother Trimester of pregnant women with complications from March - April shows 34 people scattered in 14 villages working area Health Center in Kedu Regency Temanggung (Dinkes Temanggung, 2017).

In prevention of pregnancy complications, midwives are expected to act as facilitators and can build persuasive and equal communication in their working areas to materialize cooperation with mothers, family, and society so that they can eventually increase public awareness of the health improvement efforts of mothers and newborns. One of the midwives strategies in establishing persuasive communication is to provide health counseling.

Preliminary study results that researchers have done on December 14, 2018 against 10 respondents of high risk expectant mothers in the work area of Kedu Temanggung District, Health Center shows the overall high-risk expectant mothers choose snakes and Ladders game Compared with Monopoly as a learning medium because it is more familiar, simpler and shorter playing time.

Purpose. The aim of this study was to analyse the influence of health education by using snakes and ladders game toward knowledge level about complications prevention among high risk pregnant women at the first trimester.

Methods. This was a pre experiment research with one group pretest posttest design. Sampling technique was saturated sampling method. The independent variable was health education by using snakes and ladders game while the dependent variable was knowledge level about complications prevention in high-risk pregnant women at the first trimester. The population in this research was all of the high-risk expectant mothers of the first trimester in the district health care area of Kedu Temanggung during March-April 2019, amounting to 34 people. Univariate analysis in this study uses categoric data with an ordinal scale. The analysis in this study is highrisk expectant mothers data given health education by simulating snakes and ladders covering high-risk pregnant mothers.

In analysis bivariate data to measure the level of knowledge of high risk pregnant mothers. Questionnaire was used in this study with the numerical data in the ratio scale. The test used in bivariate analysis is the Wilcoxon test. The knowledge of highrisk expectant mothers is tested in the same group so that the data gained in the form of group data is paired. The test aims to assess the high risk of pregnant women's knowledge level before and after health education with snakes and ladders simulation.

\section{Results And Discussion.}

1. Univariate Analysis

The results of research based on the frequency distribution of respondents. Knowledge level before the simulation of snakes and ladders showed that there are 27 respondents (79.4\%) have poor information about the risk of first trimester. After the simulation of snakes and ladders about the prevention of complications of high risk pregnant at the first trimester shows that most of the respondents have a good knowledge, its about 20 respondents $(58.8 \%)$ and 14 respondents $(41.2 \%)$ that have a sufficient level of knowledge about the prevention of complications. 
Based on the distribution of the total answers of respondents before and after obtaining simulated snakes and ladders, before the health education with snakes and ladders simulated, based on knowledge level criteria (Wawan and Dewi, 2010; H. 18 ), questions that can be answered properly with good criteria $(76 \%$ $100 \%$ ) The respondents were about numbers 7, 11, 12 and 16. After a health education with snakes and ladders simulated, based on knowledge level criteria (Wawan and Dewi, 2010; H. 18), experienced an increase in the answer before the health education performed with snakes and ladders was answered incorrectly Be true after a health education with the simulation of snakes and ladders with good knowledge level criteria (76\%$100 \%$ ), namely questions $3,4,5,8$, $10,13,14,15$, and 20.

2. Bivariate Analysis

Statistical test results by using the Wilcoxon test by looking at the acquisition value of the respondent obtained negative rank $=0$, known to no respondent who suffered a decrease in the level of their knowledge.

Result positive rank $=34$ means that the whole respondent experienced increased levels of knowledge. Result ties $=0$, then there are no respondents in the same level of knowledge (fixed). Z counting value $=5,099, \mathrm{z}$ table $=1,645 \mathrm{Zcount}$ $>\mathrm{Z}$ table and value $\mathrm{p}=0.000$, where value $p<0.05(0.000<0.05)$. Thus there is a significant difference between the results of pretests and posttests which means that the simulation of snakes and ladders against the level of knowledge of the pregnant mothers about high risk the first trimester to prevent the complications.

Conclusion and suggestions. Knowledge level about complications prevention was influenced by health education by using snakes and ladders game. Midwives should use health education method that is not monotonous for single method. Selection of learning methods such as the Socratic method with snakes and ladders simulation can be an alternative option as a health education media that can improve the activity of participants.

Health service is expected to give health care provides opportunities to improve innovation and creativity in providing health education. Health Department especially Health Promotion Section (Promkes) can design and popularize health education media that can attract attention and activity in health education activities

It is hoped that researchers can then continue this research with larger quantities of samples and use the control group so that they can be generalized and comparative in research and can be researched by method or medium. Other learning.

\section{References}

Dinas Kesehatan Kabupaten Temanggung. 2017. Profil Kesehatan Puskemas Kedu. Kabupaten Temanggung: Dinas Kesehatan Kabupaten Temanggung

Kementerian Kesehatan Republik Indonesia. 2014. InfoDATIN Mother's Day, InfoDATIN, pp. 3-5 Manuaba, I. B. 2009. Buku Ajar Patologi Obstetri. Jakarta: EGC

Marmi, Suryaningsih, A. R. M. dan Fatmawati, E. 2016. Asuhan Kebidanan Patologi. Yogyakarta: Pustaka Pelajar 